\title{
MOTIVASI, LOCUS OF CONTROL DAN KOMPETENSI PENGARUHNYA TERHADAP KINERJA PEREMPUAN BERWIRAUSAHA BINAAN ALISA KHADIJAH
}

\author{
Oleh:
}

\author{
Sri Lestari Prasilowati1); Ina Marlina2); Eka Avianti Ayuningtyas ${ }^{3)}$ \\ Sekolah Tinggi Ilmu Ekonomi IPWI Jakarta1;3); Alisa Khadijah Jakarta2) \\ widiyantoterry@yahoo.com ${ }^{1)}$;ina.irfan@yahoo.co.id²); eka.avianti@gmail.com $\left.{ }^{3}\right)$
}

\begin{abstract}
ABSTRAK
Tujuan penelitian yaitu : 1) Untuk menganalisis pengaruh Motivasi, Locus of Control dan Kompetensi secara simultan terhadap Kinerja Perempuan Berwirausaha Binaan Alisa Khadijah di Mega Bekasi Hypermall. 2) Untuk menganalisis pengaruh Motivasi, Locus of Control dan Kompetensi secara parsial terhadap Kinerja Perempuan Berwirausaha Binaan Alisa Khadijah di Mega Bekasi Hypermall.

Metode penelitian survey. Jenis penelitian kualitatif dan kuantitatif, pengujian instrumen dengan uji validitas, reliabilitas, normalitas, homoskedastisitas, dan multikolinieritas. Populasi dalam penelitian ini adalah perempuan berwirausaha binaan Alisa Khadijah di Mega Bekasi Hypermall sebanyak 100 orang. Tehnik pengambilan sampel dengan metode sensus dengan sampel 100 orang. Metode analisis data dengan statistik dibantu pengolahannya dengan Program SPSS.

Hasil penelitiannya terdapat pengaruh variabel X1 (Motivasi), variabel X2 (Locus of Control) dan variabel X3 (Kompetensi) secara simultan terhadap variabel Y (Kinerja Perempuan Berwirausaha) signifikan karena nilai Fhitung sebesar 308,450. Motivasi, Locus Of Control dan Kompetensi berpengaruh terhadap Kinerja Perempuan Berwirausaha sebesar 90,6\%. Terdapat pengaruh variabel X1 (Motivasi) terhadap variabel Y (Kinerja Perempuan Berwirausaha) sebesar 0,360. Terdapat pengaruh variabel variabel X2 (Locus of Control). Terdapat pengaruh variabel X3 (Kompetensi) terhadap variabel Y (Kinerja Perempuan Berwirausaha) sebesar 0,244.
\end{abstract}

Kata Kunci : Motivasi, Locus of Control, Kompetensi dan Kinerja Perempuan Berwirausaha

Kata kunci:

Motivasi, Locus of Control, Kompetensi dan Kinerja Perempuan Berwirausaha

\section{PENDAHULUAN}

UMKM harus diberdayakan menjadi lebih baik sehingga dapat mengena sasaran. Artinya pelaku usaha harus terus dibina agar lebih berkualitas dan terus berwirausaha. Kekuatan UMKM menjadi titik perekonomian bangsa yang kuat dan harus ditingkatkan. Kekuatan kewirausahaan sebagai kekuatan pembaharuan, pembangunan ekonomi dan prestasi pribadi menciptakan banyak bentuk kewirausahaan, termasuk organisasi formal dan informal (Harbi dan Anderson, 2010). 
Alisa Khadijah di bawah naungan Ikatan Cendekia Muslim Indonesia (ICMI) yang memiliki cabang-cabang di seluruh Indonesia memberikan pembinaan kepada kaum perempuan untuk berwirausaha. Alisa Khadijah Cabang Bekasi juga memiliki visi ke arah tersebut dan memberikan akses kepada kaum perempuan dalam menjalankan usahanya. Kinerja perempuan berwirasausaha dari tahun ke tahun mulai menurun hal ini dapat dilihat dari peran mereka yang semakin menurun dalam berbagai kegiatan promosi. Banyak perempuan yang berwirausaha secara kualitas belum naik ke level yang lebih baik dalam bertambahnya secara finansialnya, kemasan produk dan luasnya jaringan pemasaran. Walaupun disadari bahwa semakin bertambah secara kuantitas perempuan yang berwirausaha namun rata-rata kualitasnya masih stagnan atau bahkan menurun.

Alisa Khadijah Cabang Bekasi terus memberikan pembinaan agar motivasi mengawali untuk berwirausaha kaum perempuan kuat dan terus berusaha dengan keras dengan keyakinan yang tinggi bahwa dirinya pun dapat berhasil. Motivasi berwirausaha bagi perempuan memang bermacam-macam motivasinya, ada yang memang tekanan ekonomi rumah tangga, keinginan kebebasan finansial, keinginan untuk berbagi, keinginan untuk beraktualisasi dan masih banyak lagi alasan bagi perempuan dalam mengambil keputusan untuk berbisnis. Kewirausahaan merupakan sumber penting kerja bagi perempuan dan sumber pendapatan bagi diri mereka dan keluarga mereka (Tandrayen-Ragoobur, Verena Kasseeah, Harshana, 2012). Hal ini didukung oleh pendapat Carter et al. (2003) mengungkapkan bahwa faktor pendorong yang paling populer adalah keinginan bagi perempuan berwirausaha untuk mencapai keamanan finansial.

Locus of control yang dimiliki kaum perempuan sangat kuat sehingga ini menjadi kekuatan bagi perempuan untuk mewujudkan cita-citanya. Banyak perempuan yang berwirausaha dalam mengawali usahanya merasa tidak yakin bahwa dirinya mampu menjalankan usahanya menjadi lebiih besar. Harus disadari bahwa perempuan memiliki kekuatan yang besar dalam membangun dirinya untuk berbisnis. Perempuan memiliki jaringan yang lebih luas, kemampuan berkomunikasi yang menguat dalam diri perempuan menjadi kekuatan dalam membangun jaringan bisnisnya (Mahmudah, 2014).

\section{TUJUAN PENELITIAN}

Untuk menganalisis pengaruh Motivasi, Locus of Control dan Kompetensi terhadap Kinerja Perempuan Berwirausaha Binaan Alisa Khadijah di Mega Bekasi Hypermall.

\section{TELAAH LITERATUR DAN PENGEMBANGAN HIPOTESIS \\ Kinerja}

Kinerja adalah hasil kerja yang dapat dicapai seseorang atau sekelompok orang dalam suatu organisasi, sesuai dengan wewenang dan tanggung jawab masingmasing dalam upaya mencapai tujuan organisasi bersangkutan secara legal, tidak melanggar hukum dan sesuai dengan moral maupun etika (Sedarmayanti 2007: 260) "Kinerja merupakan salah satu aspek harga diri, apabila harga diri rendah maka kinerja yang bersangkutan juga rendah." Hadari Nawawi (2006: 63) mengatakan bahwa "Kinerja adalah (a) sesuatu yang dicapai, (b) prestasi yang diperlihatkan, (c) kemampuan kerja". Definisi lain 
mengenai kinerja menurut Hadari Nawawi (2006: 63) adalah "Kinerja dikatakan tinggi apabila suatu target kerja dapat diselesaikan pada waktu yang tepat atau tidak melampui batas waktu yang disediakan".

Kinerja kewirausahaan perempuan berwirausaha adalah kegiatan untuk mencapai tingkat tertentu dari suatu standar yang diinginkan (Kamus Besar BI, 1993). Kinerja juga disebut bagian individu/orang yang bekerja secara efektif dalam suatu organisasi.

Menurut Robbins (2006) mengatakan hampir semua cara pengukuran kinerja mempertimbangkan hal-hal sebagai berikut.

1. Kuantitas, yaitu jumlah yang harus diselesaikan atau dicapai.

Pengukuran kuantitatif melibatkan perhitungan keluaran dari proses atau pelaksanaan kegiatan. Ini berkaitan dengan jumlah keluaran yang dihasilkan.

2. Kualitas, yaitu mutu yang harus dihasilkan (baik tidaknya). Pengukuran kualitatif keluaran mencerminkan pengukuran "tingkat kepuasan", yaitu seberapa baik penyelesaiannya. Ini berkaitan dengan bentuk keluaran.

3. Ketepatan waktu, yaitu sesuai tidaknya dengan waktu yang direncanakan. Pengukuran ketepatan waktu merupakan jenis khusus dari pengukuran kuantitatif yang menentukan ketepatan waktu penyelesaian suatu kegiatan.

\section{Motivasi}

Motivasi merupakan seluruh proses gerakan, termasuk situasi yang mendorong timbulnya kekuatan pada diri individu; sikap yang dipengaruhi untuk pencapaian suatu tujuan (Guerrero, S.Sire, B. 2000). Suatu variabel yang ikut campur tangan yang digunakan untuk menimbulkan faktor-faktor tertentu di dalam organisme, yang membangkitkan, mengelola, mempertahankan, dan menyalurkan tingkah laku menuju satu sasaran (J.P. Chaplin, 2001). Motivasi awal mendirikan usaha merupakan bagian dari kepribadian. Motivasi awal mendirikan usaha adalah dorongan yang menyebabkan individu mulai menjalankan usahanya sendiri. Variabel ini digunakan untuk melihat kaitan antara antusiasme wirausaha dalam memulai usaha dengan keinginannya untuk mengembangkan usaha. Hal ini didasarkan pada asumsi bahwa wirausaha yang memulai usahanya dengan ambisi yang kuat akan memiliki keinginan yang lebih kuat pula untuk berkembang. Terdapat berbagai alasan yang mendorong seseorang mengambil keputusan menjadi wirausaha. Alasanalasan tersebut dapat dikelompokkan menjadi push factors dan pull factors (Kirkwood, 2009; Williams dkk, 2009; Liao dkk, 2001) Push factors merupakan faktor negatif yang memaksa seseorang untuk menjadi wirausaha seperti kesulitan mencari pekerjaan, gaji yang tidak mencukupi, tidak mempunyai ketrampilan khusus di bidang lain, diskriminasi, konflik di tempat kerja, kehilangan pekerjaan dan sebagainya. Sebaliknya, pull factors merupakan faktor positif yang menarik seperti keinginan untuk mandiri, memanfaatkan peluang yang ada, dan keinginan meningkatkan pendapatan. Dengan kata lain, sebagian orang mendirikan usaha karena terpaksa sementara lainnya melakukannya karena ketertarikan atau pilihan hidupnya.

\section{Locus Of Control}

Kreitner \& Kinichi (2001) mengatakan bahwa hasil yang dicapai locus of control internal dianggap berasal dari aktifitas 
dirinya. Sedangkan pada individu locus of control eksternal menganggap bahwa keberhasilan yang dicapai dikontrol dari keadaan sekitarnya. Pada individu yang mempunyai external locus of control akan memandang dunia sebagai sesuatu yang tidak dapat diramalkan, demikian juga dalam mencapai tujuan sehingga perilaku individu tidak akan mempunyai peran didalamnya. Individu yang mempunyai external locus of control diidentifikasikan lebih banyak menyandarkan harapannya untuk bergantung pada orang lain dan lebih banyak mencari dan memilih situasi yang menguntungkan Kahle (dalam Riyadingsih, 2001).

Sementara itu individu yang mempunyai internal locus of control diidentifikasikan lebih banyak menyandarkan harapannya pada diri sendiri dan diidentifikasikan juga lebih menyenangi keahlian-keahlian dibanding hanya situasi yang menguntungkan. Konsep tentang locus of control yang digunakan Rotter (1966 dalam Hersey, Paul and Blanchard, Ken, 1996) memiliki empat konsep dasar, yaitu a) Potensi perilaku yaitu setiap kemungkinan yang secara relatif muncul pada situasi tertentu, berkaitan dengan hasil yang diinginkan dalam kehidupan seseorang. b). Harapan, merupakan suatu kemungkinan dari berbagai kejadian yang akan muncul dan dialami oleh seseorang. c) Nilai unsur penguat adalah pilihan terhadap berbagai kemungkinan penguatan atas hasil dari beberapa penguat hasil-hasil lainnya yang dapat muncul pada situasi serupa. d) Suasana psikologis, adalah bentuk rangsangan baik secara internal maupun eksternal yang diterima seseorang pada suatu saat tertentu, yang meningkatkan atau menurunkan harapan terhadap munculnya hasil yang sangat diharapkan.

Dengan menggunakan konsep locus of control, perilaku bekerja dapat dijelaskan ketika seorang karyawan merasakan hasil pekerjaan yang dilakukan sebagai hasil kontrol internal atau eksternal. Kontrol internal akan tampak melalui kemampuan kerja dan tindakan kerja yang berhubungan dengan keberhasilan dan kegagalan karyawan pada saat melakukan pekerjaannya. Sedangkan karyawan dengan kontrol eksternal merasakan bahwa terdapat kontrol di luar dirinya yang mendukung hasil pekerjaan yang dilakukan. Locus of control adalah persepsi seseorang terhadap keberhasilan ataupun kegagalannya dalam dalam melakukan berbagai kegiatan dalam hidupnya yang dihubungkan dengan faktor eksternal individu yang di dalamnya mencakup nasib, keberuntungan, kekuasaan atasan dan lingkungan kerja serta dihubungkan pula dengan faktor internal individu yang di dalamnya mencakup kemampuan kerja dan tindakan kerja yang berhubungan dengan keberhasilan dan kegagalan kerja individu yang bersangkutan.

\section{Kompetensi}

Pengertian kompetensi ini pada prinsipnya sama dengan pengertian kompetensi menurut Stephen Robbin (2007) bahwa kompetensi adalah "kemampuan (ability) atau kapasitas seseorang untuk mengerjakan berbagai tugas dalam suatu pekerjaan, dimana kemampuan ini ditentukan oleh 2 (dua) faktor yaitu kemampuan intelektual dan kemampuan fisik.

Lebih rinci, Spencer dan Spencer dalam Palan (2007:84) mengemukakan bahwa kompetensi menunjukkan karakteristik yang mendasari perilaku yang menggambarkan motif, karakteristik pribadi (ciri khas), konsep diri, nilai-nilai, pengetahuan atau keahlian yang dibawa seseorang yang berkinerja unggul (superior performer) di tempat kerja. Ada 
5 (lima) karakteristik yang membentuk kompetensi yakni 1). Faktor pengetahuan meliputi masalah teknis, adminstratif, proses kemanusiaan, dan sistem. 2). Keterampilan; merujuk pada kemampuan seseorang untuk melakukan suatu kegiatan. 3). Konsep diri dan nilai-nilai; merujuk pada sikap, nilai-nilai dan citra diri seseorang, seperti kepercayaan seseorang bahwa dia bisa berhasil dalam suatu situasi. 4). Karakteristik pribadi; merujuk pada karakteristik fisik dan konsistensi tanggapan terhadap situasi atau informasi, seperti pengendalian diri dan kemampuan untuk tetap tenang dibawah tekanan. 5). Motif; merupakan emosi, hasrat, kebutuhan psikologis atau dorongan-dorongan lain yang memicu tindakan.

Dengan kata lain, kompetensi adalah penguasaan terhadap seperangkat pengetahuan, ketrampilan, nilai nilai dan sikap yang mengarah kepada kinerja dan direfleksikan dalam kebiasaan berpikir dan bertindak sesuai dengan profesinya. Selanjutnya, Wibowo (2007:86), kompetensi diartikan sebagai kemampuan untuk melaksanakan atau melakukan suatu pekerjaan atau tugas yang dilandasi oleh keterampilan dan pengetahuan kerja yang dituntut oleh pekerjaan tersebut. Dengan demikian kompetensi menunjukkan keterampilan atau pengetahuan yang dicirikan oleh profesionalisme dalam suatu bidang tertentu sebagai suatu yang terpenting. Kompetensi sebagai karakteristik seseorang berhubungan dengan kinerja yang efektiv dalam suatu pekerjaan atau situasi.

Kompetensi dapat dihubungkan dengan kinerja dalam sebuah model alir sebab akibat yang menunjukkan bahwa tujuan, perangai, konsep diri, dan kompetensi pengetahuan yang kemudian memprakirakan kinerja kompetensi mencakup niat, tindakan dan hasil akhir. Misalnya, motivasi untuk berprestasi, keinginan kuat untuk berbuat lebih baik dari pada ukuran baku yang berlaku dan untuk mencapai hasil yang maksimal, menunjukkan kemungkinan adanya perilaku kewiraswastaan, penentuan tujuan, bertanggung jawab atas hasil akhir dan pengambilan resiko yang diperhitungkan.

\section{METODE PENELITIAN \\ Tempat Penelitian}

Tempat penelitian di Alisa Khadijah di Mega Bekasi Hypermall. Penelitian dilakukan pada bulan April sampai dengan September 2015.

\section{Desain Penelitian}

Desain penelitian sebagaimana di bawah ini:

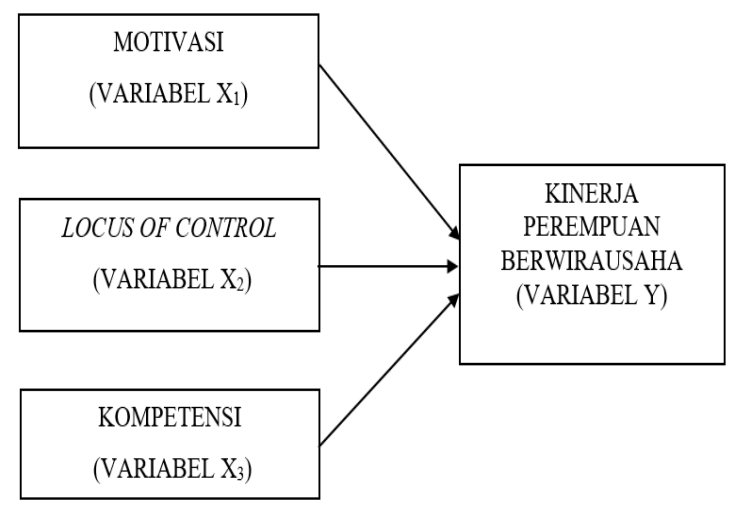

\section{Populasi dan Teknik Pengambilan Sampel}

Menurut Indriantoro dan Supomo (2001), populasi yaitu sekelompok orang, kejadian atau segala sesuatu yang mempunyai karakteristik tertentu. Populasi dalam penelitian ini adalah seluruh anggota Alisa Khadijah di Mega Bekasi Hypermall sebanyak 100 orang perempuan berwirausaha. Teknik pengambilan sampel dengan teknik jenuh yaitu mengambil sampel berdasarkan 
jumlah populasi yang ada dijadikan sampel. Sampel dalam penelitian ini 100 orang perempuan berwirausaha.

\section{Metode Analisis Data}

Metode analisis data yaitu dengan menganalisis data dengan analisis kualitatif yaitu mendeksripsikan variabelvariabel bebas dan variabel terikat. Kemudian dianalisis secara kuantitatif dengan statistik dibantu Program SPSS (Statistical Package for Social Sciences) versi 21. Adapun rumus persamaan regresi linier berganda yang digunakan dalam penelitian ini adalah:

$$
Y=a+b 1 X 1+b 2 X 2+b 3 X 3
$$

Keterangan:

$\mathrm{Y}=$ Skor responden dari $\mathrm{Y}$ (variabel nilai Y/variabel terikat)

$\mathrm{a}=$ Nilai Konstan variabel $\mathrm{Y}$

$\mathrm{b}=$ Koefisien arah regresi

$X=$ Variabel nilai $X$ (variabel nilai $\mathrm{X}$ /variabel bebas)

\section{Uji Hipotesis}

Uji regresi yaitu suatu pengujian untuk mengetahui tingkat signifikansi. Pada penelitian ini dilakukan uji regresi secara parsial dengan uji $\mathrm{t}$ dan uji regresi secara simultan dengan uji F.

\section{HASIL PENELITIAN DAN PEMBAHASAN}

Hasil Analisis Statistik dan Pengujian Hipotesis

Tabel 1

Model Summary

Pengaruh Motivasi, Locus of Control dan Kompetensi Terhadap Kinerja

Perempuan Berwirausaha

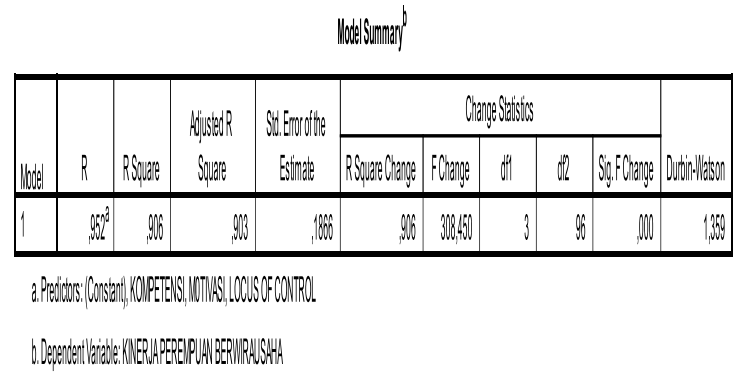

Sumber : Hasil Penelitian, 2015

Dari tabel tersebut diatas diperoleh nilai koefisien determinasi ganda (R2) sebesar 0.906 dan nilai Adj. R2 $=0.903$. Nilai R2 menunjukkan bahwa Motivasi, Locus Of Control dan Kompetensi berpengaruh terhadap Kinerja Perempuan Berwirausaha sebesar 90,6\%, sisanya sebesar $9,4 \%$ adalah pengaruh diluar variabel bebas yang diteliti seperti: disiplin, komitmen dan budaya. Sedangkan nilai koefisien determinasi parsialnya yaitu:

Kontribusi Motivasi (X1) terhadap Kinerja Perempuan Berwirausaha (Y) yaitu nilai r2 $=0,9142$ adalah 0,835 atau $83,5 \%$ sisanya sebesar $16,5 \%$ dipengaruhi oleh variabel di luar Motivasi seperti Disiplin, Budaya, Kompetensi dan lainnya.

Kontribusi Locus Of Control (X2) terhadap Kinerja Perempuan Berwirausaha $(\mathrm{Y})$ yaitu nilai $\mathrm{r} 2=$ 0,9332 adalah 0,870 atau $87 \%$ sisanya sebesar $13 \%$ dipengaruhi oleh variabel di luar Locus Of Control seperti Disiplin, Budaya, Kompetensi dan lainnya.

Kontribusi Kompetensi (X3) terhadap Kinerja Perempuan Berwirausaha (Y) yaitu nilai $\mathrm{r} 2=0,8992$ adalah 0,808 atau $80,8 \%$ sisanya sebesar $13 \%$ dipengaruhi oleh variabel di luar Kompetensi seperti Disiplin, Budaya, Komitmen dan lainnya.

Persamaan regresi linier berganda dapat dilihat pada tabel di bawah ini yaitu: 
Tabel 2

Analisis Regresi Linier Berganda

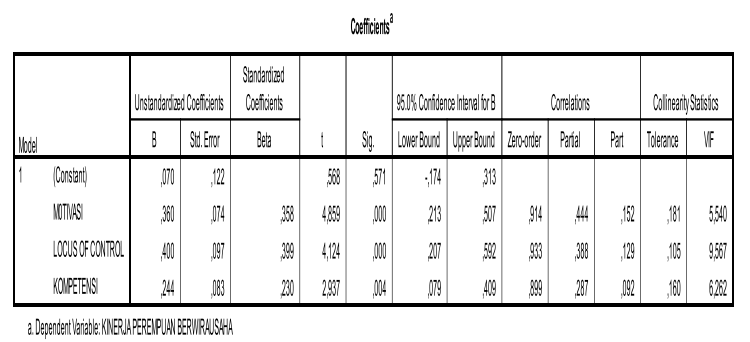

Sumber : Hasil Penelitian, 2015

Dari tabel diatas dapat pula disusun model persamaan regresi linier ganda berdasarkan kolom $\mathrm{B}$ sebagai berikut:

$$
\mathrm{Y}=\mathrm{a}+\mathrm{b} 1 \mathrm{X} 1+\mathrm{b} 2 \mathrm{X} 2+\mathrm{b} 3 \mathrm{X} 3
$$

$\mathrm{Y}=0,070+0,360 \mathrm{X} 1+0,400 \mathrm{X} 2$ $+0,244 X 3$

Model persamaan regresi linier ganda hasil analisis tersebut dapat diartikan sebagai berikut :

Nilai konstanta sebesar (a) $=0,070$, artinya bahwa jika Motivasi, Locus Of Control dan Kompetensi sama dengan 0, maka Kinerja Perempuan Berwirausaha akan tetap atau sama dengan nilai sebelumnya.

Koefisien regresi variabel $\mathrm{X} 1$ (Motivasi) sebesar 0,360, X2 dan X3 dianggap besarnya sama dengan 0 , menyatakan bahwa setiap kenaikan 1 (satu) poin nilai variabel X1 (Motivasi) meningkatkan nilai variabel $Y$ (Kinerja Perempuan Berwirausaha) sebesar 0,360 poin.

Koefisien regresi variabel $\mathrm{X} 2$ (Locus Of Control) sebesar 0,400 X1 dan X3 dianggap besarnya sama dengan 0 menyatakan bahwa setiap kenaikan 1 (satu) poin nilai variabel X2 (Locus Of Control) meningkatkan nilai variabel Y (Kinerja Perempuan Berwirausaha) sebesar 0,400 poin.

Koefisien regresi variabel X3 (Kompetensi) sebesar 0,244, X1 dan X2 dianggap besarnya sama dengan 0 menyatakan bahwa setiap kenaikan 1 (satu) poin nilai variabel X3
(Kompetensi) meningkatkan nilai variabel Y (Kinerja Perempuan Berwirausaha) sebesar 0,244 poin.

\section{Pengujian Hipotesis \\ Pengaruh Motivasi, Locus Of Control dan Kompetensi Secara Simultan Terhadap Kinerja Perempuan Berwirausaha.}

Pengaruhnya ditunjukan oleh nilai $\mathrm{F}$ hitung sebesar 308,450 memiliki tingkat signifikansi di bawah 0,05, yaitu 0,000. Artinya terdapat pengaruh variabel X1 (Motivasi), variabel X2 (Locus Of Control) dan variabel X3 (Kompetensi) secara simultan terhadap variabel $Y$ (Kinerja Perempuan Berwirausaha). Hal ini dapat dilihat pada tabel dibawah ini:

Tabel 3

Hasil Uji Anova/ Uji F

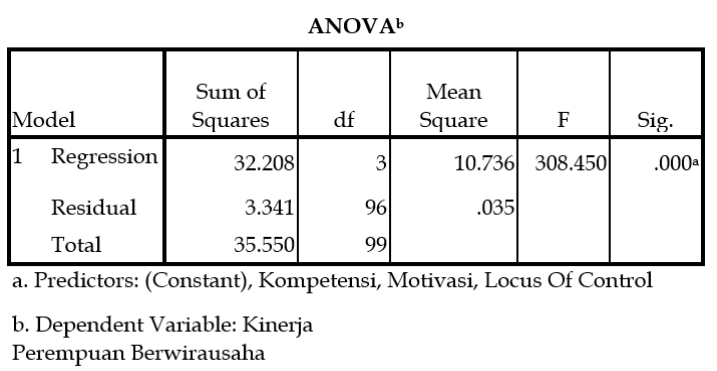

Sumber : Hasil Penelitian, 2015

Pengaruh Motivasi Secara Parsial Terhadap Kinerja Perempuan Berwirausaha.

Pengaruhnya ditujukan oleh nilai $t$ hitung variabel X1 (Motivasi) sebesar 4,859 memiliki tingkat signifikansi sebesar 0,000, karena tingkat signifikasinya di bawah 0,05 maka hasilnya signifikan.

\section{Pengaruh Locus Of Control Secara Parsial Terhadap Kinerja Perempuan Berwirausaha.}

Pengaruhnya ditujukan oleh nilai $t$ hitung variabel X2 (Locus Of Control) sebesar 4,124 memiliki tingkat signifikansi sebesar $0.000, \quad$ karena tingkat 
signifikasinya di bawah 0,05 maka hasilnya signifikan.

\section{Pengaruh Kompetensi Secara Parsial Terhadap Kinerja Perempuan Berwirausaha.}

Pengaruhnya ditujukan oleh nilai $t$ hitung variabel X3 (Kompetensi) sebesar 2,937 memiliki tingkat signifikansi sebesar 0.004, karena tingkat signifikasinya di bawah 0,05 maka hasilnya signifikan

\section{Pembahasan}

Pengaruh Variabel X1 (Motivasi), Variabel X2 (Locus Of Control) dan Variabel X3 (Kompetensi) secara simultan terhadap Variabel Y (Kinerja Perempuan Berwirausaha) ditunjukkan oleh nilai koefisien regresi linier berganda yaitu $\mathrm{Y}=$ $0,070+0,360 \mathrm{X} 1+0,400 \mathrm{X} 2+0,244 \mathrm{X} 3$ dengan nilai koefisien determinasi berganda yaitu $\left(R^{2}\right)$ sebesar 0.895 dan nilai Adj. R2 = 0.906. Nilai R2 menunjukkan bahwa Motivasi, Locus Of Control dan Kompetensi berpengaruh terhadap Kinerja Perempuan Berwirausaha sebesar 90,6\%, sisanya sebesar 9,4\% adalah pengaruh diluar variabel bebas yang diteliti seperti: Disiplin, Budaya, Komitmen dan lainnya.

Berdasarkan hasil pengujian secara simultan atau disebut uji Anova yaitu nilai F hitung sebesar 308,450 memiliki tingkat signifikansi di bawah 0,05, yaitu 0,000. Artinya terdapat pengaruh variabel $\mathrm{X} 1$ (Motivasi), variabel X2 (Locus Of Control) dan variabel X3 (Kompetensi) secara simultan terhadap variabel Y (Kinerja Perempuan Berwirausaha) signifikan.

Pengaruh Variabel X1 (Motivasi) terhadap Variabel Y (Kinerja Perempuan Berwirausaha). Berdasarkan analisis regresi linier berganda yaitu $\mathrm{Y}=0,070+$ $0,360 X 1+0,400 X 2+0,244 X 3$, nilai koefisien regresi variabel X1 (Motivasi) yang diperoleh secara positif sebesar 0,360 yang berarti bahwa setiap kenaikan variabel X1 (Motivasi) sebesar satu satuan berarti variabel Y (Kinerja Perempuan Berwirausaha) pun akan naik sebesar 0,360 . Selain Nilai thitung variabel X1 (Motivasi) sebesar 4,859 memiliki tingkat signifikansi sebesar 0,000, karena tingkat signifikasinya di bawah 0,05 maka hasilnya signifikan.

Dari hasil analisis koefisien determinasi bahwa Kontribusi Motivasi (X1) terhadap Kinerja Perempuan Berwirausaha $Y$ ) sebesar nilai $\mathrm{r} 2=0,9142$ adalah $\quad 0,835$ atau $83,5 \%$ sisanya sebesar $16,5 \%$ dipengaruhi oleh variabel di luar Motivasi seperti Disiplin, Budaya, Kompetensi dan lainnya. Hal ini menguatkan hasil penelitian Ali Yassin Sheikh Ali et al, 2013 yaitu Motivasi berpengaruh terhadap Kinerja pengusaha perempuan di Somalia. Selain itu menguatkan hasil penelitian Vivin (2013) yang menyatakan bahwa motivasi berpengaruh kuat terhadap pertumbuhan usaha.

Pengaruh Variabel X2 (Locus Of Control) terhadap Variabel Y (Kinerja Perempuan Berwirausaha). Berdasarkan analisis regresi linier berganda yaitu $\mathrm{Y}=$ $0,070+0,360 X 1+0,400 X 2+0,244 X 3$, nilai koefisien regresi variabel X2 (Locus Of Control) yang diperoleh secara positif sebesar 0,400 yang berarti bahwa setiap kenaikan variabel X2 (Locus Of Control) sebesar satu satuan berarti variabel $\mathrm{Y}$ (Kinerja Perempuan Berwirausaha) pun akan naik sebesar 0,400. Selain nilai thitung variabel X3 (Kompetensi) sebesar 4.124 memiliki tingkat signifikansi sebesar 0.000 , karena tingkat signifikasinya di bawah 0,05 maka hasilnya signifikan. Hasil koefisien determinasi parsial yaitu kontribusi Locus Of Control (X2) terhadap Kinerja Perempuan Berwirausaha $(\mathrm{Y})$ nilai r2 $=0,9332$ adalah 0,870 atau $87 \%$ sisanya sebesar $13 \%$ dipengaruhi oleh 
variabel di luar Locus Of Control seperti Disiplin, Budaya, Kompetensi dan lainnya.

Pengaruh Variabel X3 (Kompetensi) terhadap Variabel Y (Kinerja Perempuan Berwirausaha). Berdasarkan analisis regresi linier berganda yaitu $\mathrm{Y}=0,070+$ 0,360X1 +0,400X2 +0,244X3, nilai koefisien regresi variabel $\mathrm{X} 3$ (Kompetensi) yang diperoleh secara positif sebesar 0,244 yang berarti bahwa setiap kenaikan variabel X3 (Kompetensi) sebesar satu satuan berarti variabel Y (Kinerja Perempuan Berwirausaha) pun akan naik sebesar 0,244 . Selain nilai $t$ hitung variabel Kompetensi (X3) sebesar 2,937 memiliki tingkat signifikansi sebesar 0.004, karena tingkat signifikasinya di bawah 0,05 maka hasilnya signifikan. Dari hasil analisis koefisien determinasi bahwa kontribusi Kompetensi (X3) terhadap Kinerja Perempuan Berwirausaha $(\mathrm{Y})$ nilai r2 = 0,8992 adalah 0,808 atau $80,8 \%$ sisanya sebesar $13 \%$ dipengaruhi oleh variabel di luar Kompetensi seperti Disiplin, Budaya, Komitmen dan lainnya.

Hal ini memperkuat hasil penelitian Rachel (2014) yang menyatakan bahwa kompetensi berpengaruh kuat sebesar 0,892 terhadap kinerja kewirausahaan usaha kecil di Sumatera. Hasilnya didukung oleh penelitian yang dilakukan oleh Shane dan Von Glinow (2003), yang menyatakan bahwa peran persepsi menentukan seseorang rasa tanggung jawab untuk bertindak sesuai dengan peran. Ketika seseorang memiliki kemampuan dan motivasi untuk bekerja dengan baik namun dia tidak mengerti peran, itu akan menurunkan kinerja.

\section{KESIMPULAN}

Terdapat pengaruh variabel $\mathrm{X} 1$ (Motivasi), variabel X2 (Locus of Control) dan variabel X3 (Kompetensi) secara simultan terhadap variabel $Y$ (Kinerja Perempuan Berwirausaha) signifikan karena nilai Fhitung sebesar 308,450. Menunjukkan bahwa Motivasi, Locus Of Control dan Kompetensi berpengaruh terhadap Kinerja Perempuan Berwirausaha sebesar 90,6\%. Terdapat pengaruh variabel X1 (Motivasi) terhadap variabel Y (Kinerja Perempuan Berwirausaha) sebesar 0,360. Terdapat pengaruh variabel variabel $X 2$ (Locus of Control) terhadap variabel $Y$ (Kinerja Perempuan Berwirausaha) sebesar 0,400. Terdapat pengaruh variabel X3 (Kompetensi) terhadap variabel Y (Kinerja Perempuan Berwirausaha) sebesar 0,244.

\section{SARAN}

Saran-saran dalam penelitian ini yaitu sebagai berikut:

1. Motivasi memiliki pengaruh yang cukup kuat terhadap Kinerja Perempuan Berwirausaha sehingga motivasi yang diberikan harus terprogram. Artinya motivasi yang ada mengena sasaran sehingga perempuan yang berwirausaha terus bersemangat dalam menjalankan usahanya. Alisa Khadijah ICMI harus membuat program kerja yang realistis untuk perempuan yang berwirausaha dan komitmen dalam menjalankan program bukan sekedar di atas kertas. Selain itu terus meningkatkan dalam membuka akses berbagai lini dan berbagai jenis akses untuk perempuan yang berwirausaha. Locus of Control yang dimiliki perempuan berwirausaha menjadi kekuatan untuk mengendalikan diri dalam menjalankan usahanya. Tentunya kompetensi yang dimiliki pun harus terus ditingkatkan dengan berbagai pelatihan yang terprogram sehingga bermanfaat bagi perempuan 
berwirausaha secara berkelanjutan. Kompetensi kewirausahaan dalam pengelolaan keuangan, pengelolaan produk, pengelolaan promosi dan lainnya harus diberikan dengan baik sehingga perempuan berwirausaha mendapatkan pengetahuan dengan benar dan tepat tentang usaha yang dipilihnya.

2. Penelitian yang telah dilakukan ini dapat menjadi rujukan ke penelitian selanjutnya dengan responden dari wilayah lain sehingga akan mengetahui seberapa kinerja perempuan berwirausaha yang dibinanya. Selain itu lebih diperluas dan diperdalam lagi dalam pembahasan yang berkenaan dengan variabel dan indikator-indikatornya.

\section{DAFTAR PUSTAKA}

Ali Yassin Sheikh Ali dan Hussein Abdi Mahamud, 2013, Motivational Factors and Performance of Women Entrepreneurs in Somalia, Journal of Education and Practice www.iiste.org ISSN 22221735 (Paper) ISSN 2222-288X (Online) Vol.4, No.17, 201347.

Dharma, Surya. 2005, Manajemen Kinerja, Penerbit: Pustaka Pelajar, Jakarta.

Ghozali, Imam. 2005, Aplikasi Analisis Multivariate dengan Program SPSS, Edisi Ketiga, Penerbit: BPUniversitas Diponegoro, Semarang.

Gomes, Cardaso, Faustino, 2003. Manajemen Sumber Daya
Manusia. Penerbit Andi

Yogyakarta.

Mangkunegara, A. A. Anwar Prabu, 2007, Evaluasi Kinerja Sumber Daya Manusia, Cetakan Keempat, PT. Refika Aditama, Bandung.

Mangkuprawira, Tb. Syafri, 2004, Manajemen Sumber Daya Manusia Strategik, Cetakan Ketiga, Penerbit Ghalia Indonesia, Jakarta.

Nawawi, Hadari. 2003. Manajemen Strategik Organisasi Non Profit Bidang Pemerintahan. Yogyakarta: Gajah Mada University Press.

Mc Shane, S.L. \& Von Glinow, M.A. V., 2003, Organizational Behavior. New York.McGraw-Hill Irwin.

Oni Bamikole dan Foluso llesanmi Jay, 2012, Locus of Control, Gender and Entrepreneurial Ability, British Journal of Arts and Social Sciences ISSN: 2046-9578, Vol.11 No.l (2012) OBritishJournal Publishing, Inc. 2012 http://www.bjournal.co.uk/BJASS. asp 74

Robbins, SP. 2007. Perilaku Organisasi: Konsep Kontroversi, Aplikasi, Edisi Indonesia, Penerbit: PT. Prenhallindo, Jakarta.

Siagian, 2004. Teori Motivasi dan Aplikasinya, PT. Rineke Cipta, Jakarta.

Siti Mahmudah, Perempuan Berwirausaha? Why Not?, 2013. ISBN 978-979-18686-3-1. 